\title{
The Effectiveness of Village Fund Management in The Government of Tondon Langi Village, Tondon District, North Toraja Regency
}

\author{
Liberthin Palullungan $^{1}$, Yeheschiel Bartin Marewa ${ }^{2}$, Roland Kondo ${ }^{3}$ \\ Department of law, Universitas Kristen Indonesia Paulus, Makassar, Indonesia ${ }^{1,2,3}$ \\ \{marewa@ukipaulus.ac.id ${ }^{1}$ \}
}

\begin{abstract}
The village is at the forefront of development and improvement of community welfare. Villages are given the authority and adequate sources of funds in order to manage their potential to improve community welfare. Each year the central government allocates a large enough village fund to be given to villages. This study aims to determine how the management of village funds in Tondon Langi village,'Tondon District, North Toraja Regency and what factors influence the management of village funds in Tondon Langi village' North Toraja Regency. This research method is a juridical empirical research that is analyzed qualitatively descriptive. The results of the study show that the management of village funds in the village of Tondon Langi ', Tondon District, North Toraja Regency starting from planning, implementation, transparency, reporting to accountability has been implemented but the results have not been maximized. The influencing factor is the supporting factor, namely the existence of community participation and the availability of natural resources such as the availability of sand and stone mines, while the inhibiting factor is the human resources of government officials in Tondon Langi 'village which are still low and communication is not smooth as evidenced by the existence of the ego of the community who wants it. equitable development of each hamlet regardless of priority scale.
\end{abstract}

Keywords: effectiveness; management; village funds; tondon langi 'village

\section{Introduction}

The juridical articulation of the Village in Law No. 6 of 2014 explains that a village is a legal community unit that has territorial boundaries that have the authority to regulate and manage affairs of governance, development, and the interests of the local community based on community initiative, rights of origin, and/or traditional rights that are recognized and respected in the government system of the Unitary State of the Republic of Indonesia (NKRI) [1]. This means that the village is the spearhead of the welfare of the community because the village government is closest to the community [2]. The use of another name for the village in particular in Tana Toraja and North Toraja districts is called "Lembang". Administratively in Indonesia, the village is a division of administrative areas that are under sub-districts and led by the village head [3]. The village government was formed to implement the provisions of 
Law Number 23 of 2014 concerning Regional Government. Specifically governing Lembang was ratified by virtue of the Tana Toraja Regional Regulation No. 2 of 2001 Series D No. 2 concerning the district Government. At that time, Tana Toraja and North Toraja were still one regency, namely Tana Toraja Regency.

One form of effort for the welfare of the community in building the village is the strong touch of initiation, innovation, creation and cooperation between village officials and the community in realizing a common desire [4]. Village development cannot be carried out by village officials alone, but it needs support and an active role from the community. The Village Fund Allocation (ADD) aims to create a village government that can manage regional development based on their own budget priorities [5]. This is in accordance with the third point of the National Development Agenda in Presidential Decree No. 2 of 2015 concerning the 2015-2019 RPJMN Basically, each village gets a Village Fund Allocation (ADD) in accordance with their respective portions. The distribution of the Village Fund is distributed with a calculation where $90 \%$ is based on equalization (Basic Allocation) and 10\% (Formula Allocation) is based on the variables of the number of villagers, the village poverty rate, the area of the village, and the level of geographic difficulty of the village, with their respective weights. variable by $25 \% ; 35 \% ; 10 \%$; and $30 \%$. The distribution of the Village Fund is divided into two stages, namely the first stage in March at $60 \%$ and the second stage in August at $40 \%$. In relation to the provision of Village Fund budget allocations in North Toraja Regency, the District Government has provided technical instructions regarding the distribution process and the amount of the budget ceiling for each village [6].

\subsection{Source of Financial Resources Trained by Village}

The village also has finances that are managed by the Village government which comes from several sources. According to Permendagri No. 113/2014, the budget components consist of the following accounts:

a. Income, according to Permendagri No. 113 of 2014, Village Income includes all money received through village accounts which are the rights of the village within 1 fiscal year which do not need to be paid back by the village. Village income can come from: (a) the village's original income, including: village business results, village wealth yields, selfhelp and community participation, and other village income. (b) Transfers originating from: (1) the state revenue and expenditure budget transferred through the district / city revenue and expenditure budget and used for administering governance, village development, fostering and empowering the community, (2) sharing the results of district/municipal taxes city and regional retribution, (3) allocation of village funds, (4) financial assistance from Provincial/Regency Government APBD.

b. Village expenditure, which consists of: (a) expenditure in the field of village government administration, (b) the field of development implementation, (c) the sector of community empowerment, (d) the sector of unexpected.

\subsection{Village Fund Management}

Priority principles for the use of Village Funds (DJPPMD, 2015), namely: [7]

a. Justice, by prioritizing the rights or interests of all village residents without discrimination;

b. Priority Needs, by prioritizing village interests which are more urgent, more needed and directly related to the interests of the majority of village communities; and 
c. Village typology, taking into account the circumstances and realities of the typical geographical, sociological, anthropological, economic and ecological characteristics of the village, as well as changes or developments in village progress.

Factors that must be considered in village development according to Village Typology (DJPPMD, 2015) are:

a. Underdeveloped and / or Very Underdeveloped Villages are about facilities and infrastructure for fulfilling needs; and access to rural life.

b. Developing Village is about basic education facilities and infrastructure for general and social services; and basic public and social health service facilities and infrastructure.

c. Developed and / or independent villages are about suggestions and infrastructure that have an impact on the village economy and investment: village initiatives create job opportunities; appropriate technology; and investment through BUM Desa.

In Village Fund Management, there are management stages based on the Village Law, including: Planning, Implementation, Transparency, Reporting, and Accountability [8].

\section{Methodology}

The type of this research is juridical empirical which is sourced from primary and secondary materials as well as tertiary, the existing data is analyzed qualitatively descriptive. [9].

\section{Result and Discussion}

Tondon Langi Village is a village in the eastern part of North Toraja district. Located approximately $10 \mathrm{~km}$ from the city of Rantepao and approximately $325 \mathrm{~km}$ from Makassar City, the area is divided into rice fields, residential areas, gardens and bamboo forests, an area of approximately 16 hectares covering $40 \%$ of residential areas, $50 \%$ of rice fields and $10 \%$ garden. Tondon Langi' village has 3 (three) hamlets and the total area of which is rice fields approximately $50 \%$ so that the livelihoods of the people as farmers. The total population of Tondon Langi' village is 3,444 people. The level of community education is low. Classified in elementary school, junior high school, high school/vocational high school and undergraduate. Even some people have never received any education at all. The majority of people in Tondon Langi Village make farming their source of livelihood. Planning, implementation, reporting transparency and accountability processes for managing village funds in the village of Tondon Langi.

\subsection{Planning}

In the planning stage, the Village Fund Management is preceded by a Village Development Planning Consultation involving the Village Consultative organizations, the Head of the Hamlet, the Community and other community leaders. Village Fund Management Planning is carried out by capturing the aspirations and needs of the community through village deliberations. The Village Fund is one of the village income whose use is integrated with the Village Income and Expenditure Budget. Therefore, the planning program and its activities are compiled through the Village Development Planning Conference forum. Village Head Yusuf M Salurante said: "At the beginning of the first phase of the Village Fund, we 
always invited village government officials such as village consultative organizations, hamlet heads, community leaders and also the community to conduct deliberations on what development plans the community needs".

In accordance with the stages of village fund management and according to the regulations at the beginning of each year, Tondon Langi Village gets a Village Fund. The village government is active in holding village development planning deliberations which are the stages of development planning. By gathering each Hamlet Head, residents, community leaders and of course all Tondon Langi Village government officials. This is also according to what was expressed by several residents. One of the residents on behalf of Albert said: "that every year they are invited to discuss the incoming village funds".

\subsection{Implementation}

The Village Government of Tondon Langi 'has carried out the implementation of fund management in accordance with the regulations and aspirations of the community through the Village Development Planning Consultation (musrenbang village), this was revealed by the Village Head Yusuf M Salurante, saying: "In the management of the Village Fund, there is a regulation from the North Toraja Regent regarding the management of the Village Fund every year, and we carry out management according to these rules. These regulations facilitate the planning and implementation of village fund management".

The implementation of Village Fund management in Tondon Langi' Village in terms of development has not been evenly distributed in 3 (three) hamlets but it is proportional. This was disclosed by the Village Head Yusuf M Salurante, saying: "The management of the Village Fund for the three hamlets is not evenly distributed, the road construction is not the same length in the three hamlets, because we prioritize hamlets whose road access is not feasible. Lemba Hamlet is still running very well, therefore we repair more roads in Saleka and Ampangan Hamlets because the roads are already damaged".

From 2015 as the start of the Village Fund disbursement, the Tondon Langi' Village government has managed the Village Fund by building a $5.5 \mathrm{~km}$ village road which is divided into 3 (three) hamlets, namely Lemba Hamlet along $1.5 \mathrm{~km}$ with a budget of Rp. 545,000,000, Ampangan Hamlet $2 \mathrm{~km}$ with a budget of Rp. 727,000,000, and Saleka Hamlet $2 \mathrm{~km}$ long with a budget of Rp. 727,000,000. Development of Integrated Healthcare Center (Posyandu) in each hamlet with a budget of Rp. 150,000,000 per hamlet. Development of Kindergarten which is still in the $50 \%$ stage with an initial budget of Rp. 100,000,000. The village government also budgeted the operational costs for Posyandu of Rp. 16,000,000 per year and the operational costs for kindergarten of Rp. 12,000,000 per year (Table 1). The Tondon Langi' Village Administration has carried out the implementation of Village Fund management based on technical guidelines, namely the North Toraja Regent Regulation on the Implementation of Lembang Tondon Langi' Income and Expenditure. From this implementation, the people of Tondon Langi Village are now starting to feel the benefits of the Village Fund through several infrastructure developments.

Table 1. List of Development for each Village

\begin{tabular}{llcc}
\hline Hamlet name & Type of development & $\begin{array}{c}\text { Development Fund } \\
\text { Budget (Rp) }\end{array}$ & $\begin{array}{c}\text { Operational Cost } \\
\text { (Rp) }\end{array}$ \\
\hline \multirow{3}{*}{ Lemba Hamlet } & 1.5 km village road & 545 million & \\
& Integrated Healthcare & 150 million & 16 million / year \\
& Center & 100 million & 12 million / year
\end{tabular}




\begin{tabular}{llcc}
\hline Hamlet name & Type of development & $\begin{array}{c}\text { Development Fund } \\
\text { Budget (Rp) }\end{array}$ & $\begin{array}{c}\text { Operational Cost } \\
\text { (Rp) }\end{array}$ \\
\hline \multirow{2}{*}{ Saleka Hamlet } & 2 km village road & 727 million & \\
& Integrated Healthcare & 150 million & 16 million / year \\
& Center & 727 million & \\
Ampangan & 2 km village road & 150 million & 16 million / year \\
Hamlet & Integrated Healthcare & Center &
\end{tabular}

The delivery of community management of village funds in terms of development looks like road construction and posyandu, but has not yet been maximized.

\subsection{Transparency}

Starting with the socialization by presenting the head of the hamlet, the village consultative body, community leaders and several people who wanted to attend to discuss the amount of incoming village funds and their management. The village government is open to anyone who wants to know the use of village funds.

\subsection{Reporting}

The financial reporting process for the village of Tondon Langi 'is carried out according to existing regulations.

\subsection{Accountability}

In terms of accountability, the village head of Tondon Langi 'submits the accountability report for the realization of the Village Revenue Budget implementation to the North Toraja Regent through the Tondon sub-district head at the end of each fiscal year.

\subsection{Factors Affecting the Management of Village Fund in Todon Langi' Village}

\section{a) Supporting factors, namely natural resources and facilities}

The availability of resources and facilities plays an important role in the management of the Village Fund in Tondon Langi Village '. Such as the availability of sand and stone mines so that they can be obtained at a lower cost. The facilities are also very supportive in the form of trucks that are provided voluntarily from the community to transport materials for construction. The village government only buys fuel to transport materials.

\section{b) The inhibiting factor is human resources}

Human resources have a very important role to think about how to manage village funds that are good for the welfare of village communities. It turns out that human resources working in Tondon Langi Village are still low. Education on average is only SMA / SMK graduates so the ability to manage village funds is not optimal. The level of education of Tondon Langi' Villange apparatus can be seen in the foolowing Table 2. 
Table 2. The level of education of Tondon Langi' Village apparatus

\begin{tabular}{cllll}
\hline No. & \multicolumn{1}{c}{ Name } & Gender & \multicolumn{1}{c}{ Position } & Last Education \\
\hline 1 & Yusuf M Salurante & Male & Village head & Senior high school \\
2 & Winta Panimba,S.E. & Female & village secretary & Bachelor \\
3 & Ferianti Sanda B. & Male & head of financial affairs & Senior high school \\
4 & MagdalenaPama'tan & Female & head of general affairs & Senior high school \\
5 & Petrus Karre & Male & head of government section & Senior high school \\
6 & Sara Lenianni S. & Female & head of service section & Senior high school \\
7 & Yunus Pammai' & Male & head of the welfare section & Senior high school \\
8 & Rannu Patibong & Male & the head of the Lemba hamlet & Elementary school \\
9 & Simon Tanggulungan & Male & the head of the Ampangan hamlet & Elementary school \\
10 & Petrus Mangetan & Male & the head of the Saleka hamlet & Elementary school \\
\hline
\end{tabular}

Apart from the low level of education of the Tondon Langi' Village government apparatus which is an obstacle, there are still other inhibiting factors, namely communication. People often tend to be selfish in submitting planning suggestions. They want an even distribution of development in each hamlet, such as road construction in each hamlet evenly, even though there are hamlets whose road conditions are still decent, while other hamlets still really need a touch of road construction. In this case the village government carries out development in accordance with the regent's regulation, namely prioritizing the implementation of development in hamlets that need development first.

\section{Conclusion}

The management of village funds in the Tondon Langi' Village, Tondon District, North Toraja Regency starting from planning, implementation, transparency, reporting to accountability has been implemented but the results have not been maximized. The influencing factors are supporting factors, namely the existence of community participation and the availability of natural resources such as the availability of sand and stone mines, while the inhibiting factor is the human resources of government officials in Tondon Langi village which are still low and communication is not smooth as evidenced by the existence of community egos. who want an even development of every hamlet without paying attention.

\section{Acknowledgment}

The author would like to state appreciation to the Universitas Kristen Indonesia Paulus (UKI Paulus) in Makassar, Indonesia for supporting to publish this article

\section{References}

[1] Baroka Utami, Karmaji, Sugiarto, Suchaini, Widyaningsih, Hurcahyo, Rahmtama, and Abduh, "Indeks Pembangunan Desa 2014" [Village Development Index 2014], Jakarta, Badan Perencanaan Pembangunan Nasional [National Development Planning Agency], 2015

[2] Edi Suharto, "Membangun masyarakat memberdayakan masyarakat" [Building the community empowers the community], Bandung, Refika Aditama, 2010. 
[3] A.W Wijaya, "Pemerintahan desa/Marga" [Village / clan government], Jakarta, PT Raja Grafindo Persada, 2003

[4] Liberthin Palullungan, "The Role of Local Regulation in Realizing The Welfare of Communities in Sikka District", Journal of Advanced Research in Dynamical and Control Systems, vol.11, special Issue-08, pp. 2954-2960, 2019.

[5] Redaksi Sinar Grafika, "Peraturan lengkap Desa (UU RI Nomor 6 Tahun 2014)" [Complete Village Regulation (RI Law Number 6 Year 2014), Jakarta, Sinar Grafika, 2016.

[6] Eko, Sutoro, "Regulasi Baru, Ide, Misi, dan Semangat Undang-Undang Desa", [New Regulations, Ideas, Missions, and Spirit of Village Laws], Jakarta, Kementerian Desa, Pembangunan Daerah Tertinggal, dan Transmigrasi Republik Indonesia [The Ministry of Villages, Development of Disadvantaged Areas, and Transmigration of the Republic of Indonesia], 2015.

[7] Direktorat Jenderal Pembangunan dan Pemberdayan Masyarakat [Directorate General of Community Development and Empowerment], "Pokok-pokok Kebijakan Prioritas Penggunaan Dana Desa" [Principles of Priority Policy for the Use of Village Funds], 2016.

[8] Numan, "Strategi Pembangunan Daerah" [Regional Development Strategy], Jakarta, Raja Grafindo Persada, 2015.

[9] Peter Macmud Marzuki, "Penelitian Hukum" [Legal Research], Jakarta, Kencana, 2010. 